\title{
Evaluation of the Efficiency of Certain Attractive Toxic Baits for the Control of the House Fly, Musca domestica (Diptera: Muscidac)
}

\section{Amin $\mathrm{AA}^{1}$, Soliman $\mathrm{MH}^{1}$ and Shalaby $\mathrm{AA}^{2 *}$}

${ }^{1}$ Chemistry Department, Faculty of Science, Helwan University, Cairo, Egypt

${ }^{2}$ Research Institute of Medical Entomology, The General Organization for Teaching Hospitals and Institute, Dokki, Giza, Egypt

\begin{abstract}
The efficiency of boric acid, borax and imidacloprid is evaluated for inhibition of adult house fly emergence (IC values) as dry and liquid baits. In the two cases, imidacloprid has the greatest fatal effect at both $I C_{50}$ and $I C_{90}$ levels followed by boric acid and then borax. In the liquid formulation, $I C_{50}$ and $I C_{90}$ values are $(0.083$ and $2.6 \%),(0.19$ and $2.48 \%)$ and $(2.6$ and $16.9 \%)$ for three tested compounds respectively. The relative efficiency for imidacloprid and boric acid compared to borax (the least potent one), imidacloprid and boric acid achieved 31.3 and 13.7 times more suppression of adult emergence than borax. In the solid formulation, $\mathrm{IC}_{50}$ and $\mathrm{IC}_{90}$ values are $(0.083-0.67 \%)$ followed by boric acid (3.7-11.6\%) and borax (5.74-21.1\%) respectively. It's clear that imidacloprid 68.8 times and boric acid 1.5 times as toxic as borax. Reasons for differences in manifestation of mortality and possibilities for practical application are discussed. We conclude that the efficiency of tested compounds as liquid baits is higher than it as dry baits.
\end{abstract}

Keywords: Efficiency; Boric acid; Borax; Imidacloprid; House fly

\section{Introduction}

The common house fly (Diptera: Muscidae) continues to be a nuisance and acts as an important mechanical vector of pathogenic organism. Flies feeds and breeds in manure, excrement, garbage, sewage sludge and fermenting crop wastes and other sources of filth, where they can pick up and transport various diseases agents amongst humans and animals. Medically important pathogens such as bacteria, fungi, viruses, warms protozoa and nematodes were isolated on the house fly surface [1-5]. Flies have rapid, prolific breeding habits high, mobility and short life cycle, it a difficult control. In order to break the life cycle, control measures should be direct against larvae and adult flies. The traditional and the most extensive control technique used for the suppression of house fly population has been the application of residual contact insecticides. As a result of continuous use of insecticides to control flies, the problem of resistance began to appeal. House fly insecticides resistance is global problem [6-9] and has specifically been documented in Egypt [10-14]. Historically house flies have shown great propensity to develop insecticide resistance, new methods need to be evaluated to prevent future control failures. Toxic baits have been an important tool in fly management program. Localized toxic target technique, like insecticide application through baits is advantageous as not only decrease the risk of resistance developing in flies but also greatly reduce the amount of insecticides released into environment. Also, conservation of predators and parasites of immature stages of house flies $[15,16]$. Recently, a new promising strategy based on attract and kill for controlling vectors of diseases called attractive toxic sugar bait (ATSB) method. Introduction of ATSB on bait stations have been successful against vectors of diseases in different parts of the world [1719]. In this method, vectors are attracted to a surface or vegetation that applied with ATSB containing toxins such as organic compound (e.g., imidacloprid, azamethiphos, fipronil, methomyl and chlorpyrifos) or inorganic compound (Boron compounds). Neonicotinoid insecticides are the new class of insecticides and have higher selectivity factor for insect versus mammals [20,21]. Imidacloprid is an insecticide belonging to chloronicoting class compound. It is effective against a wide range of nuisance and public hygiene insect species [22-26]. Insecticides containing boron have a long history of use in pest control [27]. Boroncontaining compound, especially boric acid and its sodium salts (e.g., borax, disodium octaborate and sodium metaborate) have been use routinely for fly control before the advent of chlorinated hydrocarbons and DDT, but it was used primarily as larivicid [28]. Boric acid and borax still remains a very safe and useful chemical acting as a contact insecticide and as stomach poison. Recent research had demonstrated efficacy of boron compound against several household pests [29-36]. Sub lethal doses concentrations of insecticides have been shown to cause latent toxicity [37]. Sub lethal effect is expressed as physiological impact on individuals that survive an exposure to an insecticide [38], for example, in changes of biological parameter, longevity, reproduction, fertility of eggs, pupation, adult emergence and development in the life history. Several biological effects are reported in the literature due to the use of sub lethal doses concentrations of insecticides [3942]. Insecticide mixtures have been proposed as important tools for resistance management in different insect pests. Insecticide mixtures could enhance the toxicity of insecticides in different resistant insects [43-47].

The present study was carried out with three objectives:

- To evaluate the toxicity of sugar baits containing boric acid, borax and imidacloprid against larvae and adult of house fly in liquid and dry formulations

- Latent effects resulted from treated larvae and adults with sub lethal concentrations of ATSB

- Efficacy of combination of imidacloprid with boric acid or borax.

*Corresponding author: Shalaby AA, Research Institute of Medical Entomology The General Organization for Teaching Hospitals and Institute, Dokki, Giza, Egypt, Tel: +20223648073; E-mail: ashraf.yasein@yahoo.com

Received August 26, 2017; Accepted August 29, 2017; Published September 06, 2017

Citation: Amin AA, Soliman MH, Shalaby AA (2017) Evaluation of the Efficiency of Certain Attractive Toxic Baits for the Control of the House Fly, Musca domestica (Diptera: Muscidac). Chem Sci J 8: 170. doi: 10.4172/2150-3494.1000170

Copyright: ( 2017 Amin AA, et al. This is an open-access article distributed under the terms of the Creative Commons Attribution License, which permits unrestricted use, distribution, and reproduction in any medium, provided the original author and source are credited. 
Citation: Amin AA, Soliman MH, Shalaby AA (2017) Evaluation of the Efficiency of Certain Attractive Toxic Baits for the Control of the House Fly, Musca domestica (Diptera: Muscidac). Chem Sci J 8: 170. doi: 10.4172/2150-3494.1000170

Page 2 of 8

\section{Materials and Methods}

\section{Insecticides tested}

The insecticides tested included two inorganic compounds (boric acid and borax) and one organic compound (imidacloprid).

\section{Inorganic compound}

a) Boric acid:

Common name: Boric acid (Orthoboric acid, Boracic acid, Borofax)

Chemical name: Trihydrooxidoboron

Chemical furmula: $\mathrm{BH}_{3} \mathrm{O}_{3}$ or $\mathrm{B}(\mathrm{OH})_{3}$

b) Borax.

Common name: Borax (Sodium borate, Sodium tetraborate, Disodium tetraborate).

Chemical name: Sodium tetraborate decahydrate

Chemical formula: $\mathrm{Na}_{2} \mathrm{~B}_{4} \mathrm{O}_{7} \cdot 10 \mathrm{H}_{2} \mathrm{O}$

Organic compound (Imidacloprid)

Common name: Imidacloprid (Admire, confidor, Pravado)

Chemical name: 1-(6-chloro-3-pyridylmethy)-Nnitroimidazliodin-2-ylideneamine.

Chemical formula: $\mathrm{C}_{9} \mathrm{H}_{10} \mathrm{CIN}_{5} \mathrm{O}_{2}$

Tested insect

House fly, Musca domestica

Family: Muscidae

\section{Order: Diptera}

Adult house flies were collected from garbage dumps, Giza Governorate by insect's net as a field strain and transferred to the laboratory. Adults were maintained in cubical cage, $35 \mathrm{~cm}$ in each direction. It is constructed of wood frame, covered with Iron network on top and sides. The bottom is made of a movable metallic sheet to facilitate cleaning. The front side was provided with a wooden frame with muslin cloth sleeve, which was used for handling the insects, and introducing the food. The adult flies were provided with cotton ball saturated with $10 \%$ milk solution containing $2 \%$ sugar held in petri dish for feeding and served as a medium for oviposition. The food was replaced every day.

Eggs were remove from cotton ball and placed on the top of rearing medium in glass jar. The jar top was covered with muslin square held in place by two rubber bands. The breeding medium of larvae consists of wheat bran, yeast, powder milk and water, in the ratios of 20:1:2:20 parts respectively [48-51].

Different larvae instars were reared on larval medium until pupation. The late third instar larvae migrate to the upper layer of the medium to pupate. The dry top layer of media in each jar was removed and transferred to a basin. A stream of air was used for separating the pupae from dried medium. The pupae were transferred to adult breeding cages for emergence. The population was reared at $27 \pm 1^{\circ} \mathrm{C}$ and $65 \pm 5 \%$ relative humidity $(\mathrm{RH})$.

\section{Preparation of Attractive Toxic Sugar Baits (ATSB)}

ATSB solution: Sugar bait solution was made by adding sugar to water at rate of $10 \%$. Boric acid, borax was added directly to sugar solution $10 \%$ to obtain serials concentrations. Imidacloprid was dissolve in alcohol before added to sugar solution $10 \%$.

ATSB dry: The baits were prepared by mechanically mixing technical insecticide with granulated sugar or prepared by mixing alcohol solutions of technical grad insecticides with granulated sugar and allow the solvent to evaporate. Tested application treatments:

Larval bioassay: The breeding medium of larvae was prepared as described above. ATSB solution mix with larval medium to produce a serial concentration as follows:

-For imidacloprid (0.02- 0.32\%)

-For boric acid (0.125 - 4\%)

-For borax (1-12\%).

Another experiment for ATSB dry formulation, the range of concentration tested was as follows:

(0.024 to $0.38 \%$ ) for imidacloprid, (2 to $12 \%)$ for boric acid and (2 to 16\%) for borax. Small plastic cups were filled with five grams of larval medium. Twenty-five third instar larvae were used per treatment. Control groups provided with untreated medium (rearing medium plus sugar solution $10 \%$ or granules sugar). Each insecticides concentration and sugar control for each insecticide were replicated four times. Mortality of larvae was observed daily until pupation. The number of pupae and adults emerging were recorded.

\section{Results and Discussion}

\section{Effects of ATSB on the development of house fly larvae}

ATSB as liquid baits: The development of third instar larvae of house fly Musca domestica was affected by imidacloprid, boric acid and borax treatment of larval medium as ATSB liquid baits (Tables 1-3 and Figures 1-3), and the effects were concentration dependent.

\begin{tabular}{|c|c|c|c|}
\hline $\begin{array}{c}\text { Concentration } \\
(\%)\end{array}$ & $\begin{array}{c}\text { Pupation (\% } \mathbf{\pm} \\
\text { SD) }\end{array}$ & $\begin{array}{c}\text { Emergence (\% } \\
\mathbf{\pm} \text { SD) }\end{array}$ & $\begin{array}{c}\text { Inhibition of Adult } \\
\text { Emergence (\%) }\end{array}$ \\
\hline 0.0 & $100 \pm 0.0$ & $97 \pm 0.58$ & 3 \\
\hline 0.02 & $97 \pm 0.58$ & $88 \pm 0.58$ & 12 \\
\hline 0.04 & $93 \pm 0.58$ & $83 \pm 0.58$ & 17 \\
\hline 0.06 & $75 \pm 1.0$ & $65 \pm 1.0$ & 35 \\
\hline 0.12 & $47 \pm 0.58$ & $33 \pm 0.58$ & 67 \\
\hline 0.16 & $30 \pm 1.0$ & $20 \pm 1.0$ & 80 \\
\hline 0.32 & $18 \pm 0.58$ & $8 \pm 0.58$ & 92 \\
\hline
\end{tabular}

Table 1: Effect of imidacloprid on the development of the house fly in a treated medium containing third instar larvae (liquid baits)

\begin{tabular}{|c|c|c|c|}
\hline $\begin{array}{c}\text { Concentration } \\
(\%)\end{array}$ & Pupation (\% $\mathbf{\pm}$ SD) & $\begin{array}{c}\text { Emergence (\% } \\
\mathbf{\pm} \text { SD) }\end{array}$ & $\begin{array}{c}\text { Inhibition of Adult } \\
\text { Emergence (\%) }\end{array}$ \\
\hline 0 & $100 \pm 0.0$ & $85 \pm 0.58$ & 15 \\
\hline 0.125 & $97 \pm 0.58$ & $60 \pm 0.58$ & 40 \\
\hline 0.25 & $75 \pm 1.0$ & $42 \pm 0.58$ & 58 \\
\hline 0.5 & $63 \pm 1.0$ & $25 \pm 1.0$ & 75 \\
\hline 1 & $60 \pm 0.58$ & $23 \pm 0.58$ & 77 \\
\hline 2 & $48 \pm 0.58$ & $18 \pm 1.0$ & 82 \\
\hline 4 & $35 \pm 1.0$ & $0.0 \pm 0.58$ & 100 \\
\hline
\end{tabular}

Table 2: Effect of boric acid on the development of the house fly in a treated medium containing third instar larvae (liquid baits). 
Citation: Amin AA, Soliman MH, Shalaby AA (2017) Evaluation of the Efficiency of Certain Attractive Toxic Baits for the Control of the House Fly, Musca domestica (Diptera: Muscidac). Chem Sci J 8: 170. doi: 10.4172/2150-3494.1000170

Page 3 of 8

From data shown in Table 1 and Figure 4, it clears that the pupation rate was reduce at imidacloprid concentration as $0.32 \%$, only $18 \%$ of treated larvae reached the pupal state. Additional $0.92 \%$ reduction in emergence of adult was observed for the same treatment.

Observation of the effect of boric acid (Table 2 and Figure 5) on the development of larvae showed that application of $4 \%$ resulting in $65 \%$ larvae mortality and $35 \%$ pupation. This treatment prevented all exclusion of flies.

\begin{tabular}{|c|c|c|c|}
\hline $\begin{array}{c}\text { Concentration } \\
(\%)\end{array}$ & $\begin{array}{c}\text { Pupation (\% } \mathbf{\pm} \\
\text { SD) }\end{array}$ & $\begin{array}{c}\text { Emergence (\% } \\
\mathbf{\pm} \text { SD) }\end{array}$ & $\begin{array}{c}\text { Inhibition of Adult } \\
\text { Emergence (\%) }\end{array}$ \\
\hline 0.0 & $100 \pm 0.0$ & $98 \pm 0.58$ & 2 \\
\hline 1.0 & $90 \pm 0.58$ & $70 \pm 0.58$ & 30 \\
\hline 2.0 & $75 \pm 1.0$ & $55 \pm 0.58$ & 45 \\
\hline 4.0 & $65 \pm 1.0$ & $43 \pm 1.0$ & 57 \\
\hline 8.0 & $45 \pm 0.58$ & $23 \pm 0.58$ & 77 \\
\hline 10.0 & $40 \pm 0.58$ & $15 \pm 1.0$ & 85 \\
\hline 12.0 & $30 \pm 1.0$ & $8 \pm 0.58$ & 92 \\
\hline
\end{tabular}

Table 3: Effect of borax on the development of the house fly in a treated medium containing third instar larvae (liquid baits)<smiles>OB(O)O</smiles>

Figure 1: Chemical Structure: Technical grade contains 99\% active ingredient.<smiles>O=COB(O)OB(O)OC=O</smiles>

Figure 2: Technical grade contains $99 \%$ active ingredient.<smiles>O=[N+]([O-])/N=C1\NCCN1Cc1ccc(Cl)nc1</smiles>

Figure 3: Chemical Structure: Technical grade contains $95 \%$ active ingredient.
Borax also had some effects on the larval-to- pupal stage of development; however, compared with that of imidacloprid and boric acid, the effect of borax was relatively weak. The effect of borax on larvae to pupae development at high concentration of $12 \%$, the formulation of pupae was $30 \%$. Similarly, a reduction in adult emergence from the pupal stage was also observed; borax achieved $92 \%$ suppression of adult emergence (Table 3 and Figure 6). The efficiency of tested compounds is evaluated for inhibition of adult emergence (IC values). Data in Table 4 and Figure 7 revealed that, imidacloprid has the greatest fatal effect at both $\mathrm{IC}_{50}$ and $\mathrm{IC}_{90}$ levels followed by boric acid and then borax. This was represented by $\mathrm{IC}_{50}$ and $\mathrm{IC}_{90}$ values, $(0.083$ and $0.27 \%),(0.19$ and $2.48 \%)$ and (2.6 and $16.9 \%)$ for three tested compounds respectively. The relative efficiency for imidacloprid and boric acid compared to borax (the least potent one), imidacloprid and boric acid achieved 31.3 and 13.7 times more suppression of adult emergence than borax (Figure 7).

ATSB as dry baits: Data on the effectiveness of dry formulation baits of tested compounds on development of third instar larvae of housefly are shown in Tables 5-7 there was a concentration dependent relationship in the rate of pupation and adult emergence with three compounds.

The mortality of larvae reached to $73 \%$ ( $27 \%$ pupation) when the larvae were reared in media containing $0.38 \%$ imidacloprid. Also, the number of flies was reduced by $85 \%$ (Table 5 and Figure 4 ).

Data in Table 6 and Figure 5 indicated that the mortality of larvae, as reflected by percentage of larvae forming pupa was $70 \%$ (pupation $30 \%$ ) when third instar larvae fed at concentration level of $12 \%$ boric acid. At the same concentration, boric acid was able to suppress emergence of adult by $95 \%$.

Treatment of larvae medium containing third larvae with borax at the rate of $12 \%$, only $33 \%$ of larvae able to form pupae. At $16 \%$ more effective, the mortality increases to $85 \%$ (15\% pupation) and the flies emerged reduced by $90 \%$ (Table 7 and Figure 6).

Comparisons among $\mathrm{IC}_{50}$ and $\mathrm{IC}_{90}$ values showed that imidacloprid exhibited the highest effect on the inhibition of adult emergence when applied as dry formulation bait. From the probit analysis with respect of $\mathrm{IC}_{50}$ and $\mathrm{IC}_{90}$ values, imidacloprid gave (0.083-0.67\%) followed by boric acid (3.7-11.6\%) and borax (5.74-21.1\%) respectively. Regarding to the relative toxicity, it's clear that imidacloprid 68.8 times and boric acid 1.5 times as toxic as borax (Table 8 and Figure 8).
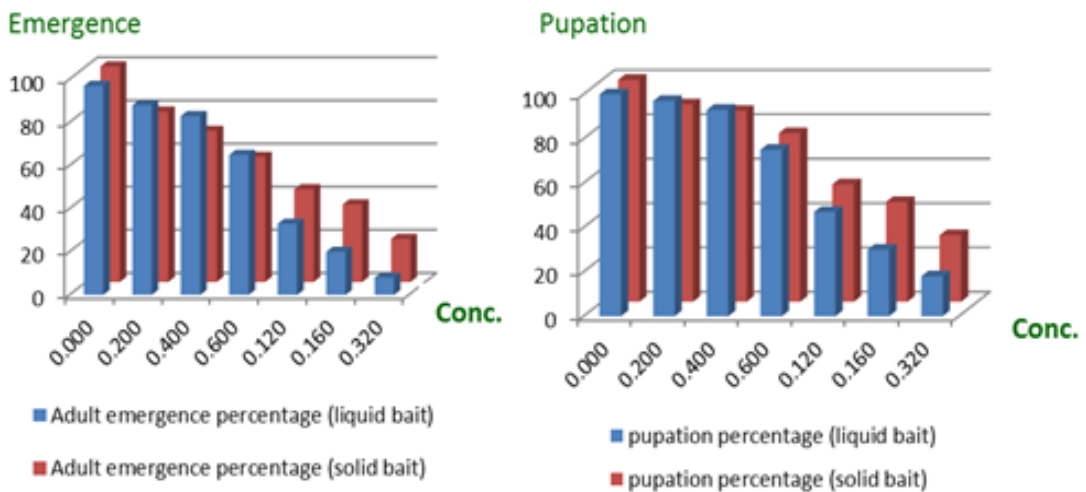

Figure 4: Effects of imidacloprid on the development of the house fly in a treated medium containing third instar larvae (liquid and solid baits). 
Citation: Amin AA, Soliman MH, Shalaby AA (2017) Evaluation of the Efficiency of Certain Attractive Toxic Baits for the Control of the House Fly, Musca domestica (Diptera: Muscidac). Chem Sci J 8: 170. doi: 10.4172/2150-3494.1000170

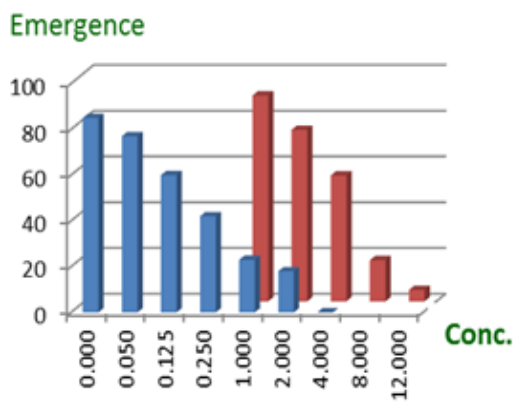

= Adult emergence percentage (liquid bait)

= Adult emergence percentage (solid bait)

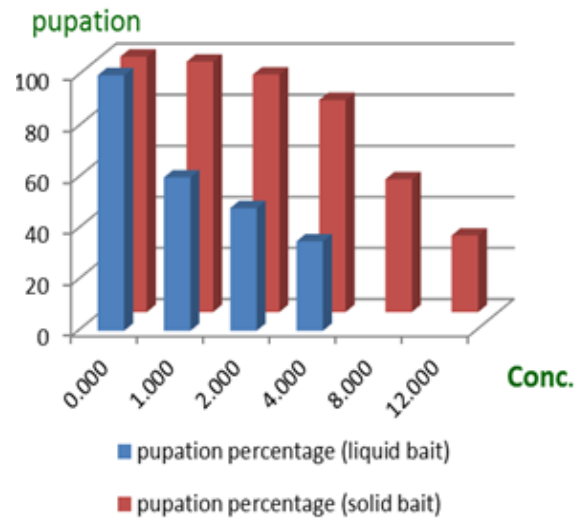

Figure 5: Effect of boric acid on the development of the house fly in a treated medium containing third instar larvae (liquid and solid baits).

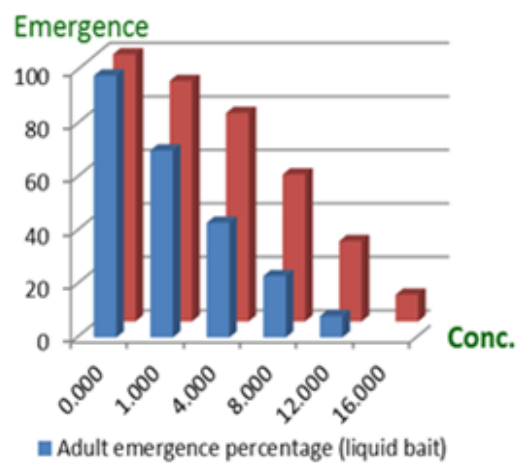

adult emergence percentage (solid bait)

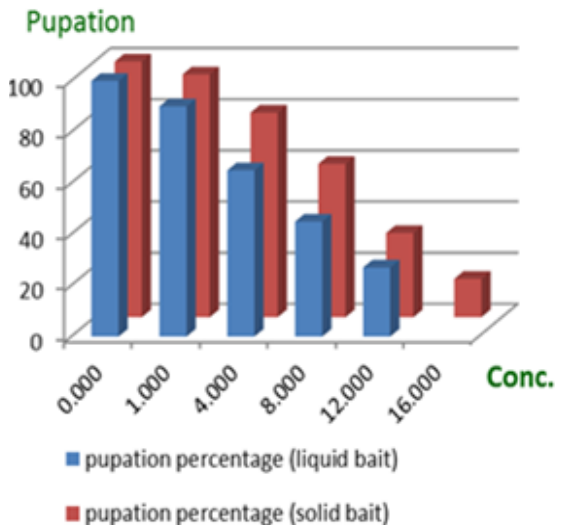

Figure 6: Effect of borax on the development of the house fly in a treated medium containing third instar larvae (liquid and solid baits).

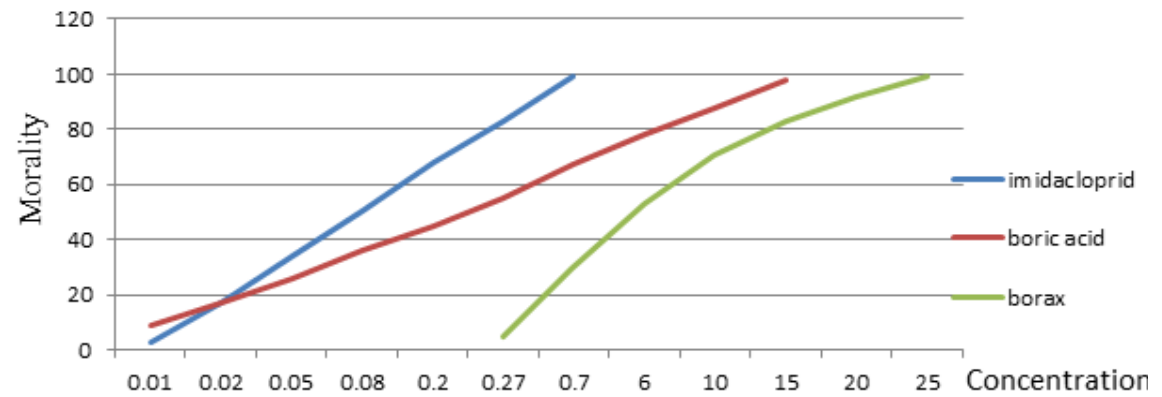

Figure 7: Imidacloprid has the greatest fatal effect at both $\mathrm{IC}_{50}$ and $\mathrm{IC}_{90}$ levels followed by boric acid and then borax.

\begin{tabular}{|c|c|c|c|c|c|c|}
\hline \multirow{2}{*}{ Compounds } & \multicolumn{3}{|c|}{ IC values \% } & \multirow{2}{*}{ IC $_{\mathbf{9 0}} \mathbf{I C}_{\mathbf{2 5}}$} & Slope & $\begin{array}{c}\text { Relative } \\
\text { Efficiency }\end{array}$ \\
\cline { 2 - 6 } & $\mathbf{2 5}$ & $\mathbf{5 0}$ & $\mathbf{9 0}$ & & & \\
\hline Imidacloprid & 0.046 & 0.083 & 0.27 & 3.3 & 2.52 & 31.3 \\
\hline Boric acid & 0.047 & 0.19 & 2.48 & 13.2 & 1.14 & 13.7 \\
\hline Borax & 1 & 2.6 & 16.9 & 44.9 & 1.59 & 1 \\
\hline
\end{tabular}

Table 4: Relative efficiency and IC values of tested compounds in liquid formulation against third instar larvae of the house fly $M$. domestica.

Attractive toxic sugar baits (ATSB) methods are new form of vector control. ATSB are highly effective method which targets flies based on their sugar foraging behavior by presenting baits of attractive compound. It is low cost and circumvents traditional problems associated with the indiscriminate effects of contact insecticides by narrowing the attraction to sugar and by using environmentally safe. Such as boron compounds that are considered to be only slightly toxic to humans [51-60]. At as a promising new tool for vector control, although imidacloprid is considered to have low oral toxicity to mammals [61-66]. Fly baits are usually applied as either dry insecticidal granular baits or as sprayable baits.

The data obtained from the present study indicate that both of solution or dry formulation baits could be used in the control of house fly. The lower concentration $\mathrm{IC}_{50}(0.083 \%)$ was observed for larvae treated rearing medium with imidacloprid in liquid and dry 
Citation: Amin AA, Soliman MH, Shalaby AA (2017) Evaluation of the Efficiency of Certain Attractive Toxic Baits for the Control of the House Fly, Musca domestica (Diptera: Muscidac). Chem Sci J 8: 170. doi: 10.4172/2150-3494.1000170

Page 5 of 8

\begin{tabular}{|c|c|c|c|}
\hline $\begin{array}{c}\text { Concentration } \\
(\%)\end{array}$ & $\begin{array}{c}\text { Pupation (\% } \mathbf{\pm} \\
\text { SD) }\end{array}$ & $\begin{array}{c}\text { Emergence (\% } \\
\mathbf{\pm} \text { SD) }\end{array}$ & $\begin{array}{c}\text { Inhibition of Adult } \\
\text { Emergence (\%) }\end{array}$ \\
\hline 0.0 & $100 \pm 0.0$ & $100 \pm 0.0$ & 0 \\
\hline 0.024 & $85 \pm 1.0$ & $70 \pm 0.0$ & 30 \\
\hline 0.048 & $80 \pm 1.0$ & $65 \pm 1.0$ & 35 \\
\hline 0.072 & $70 \pm 1.0$ & $50 \pm 1.0$ & 50 \\
\hline 0.096 & $55 \pm 1.0$ & $45 \pm 1.0$ & 55 \\
\hline 0.192 & $40 \pm 1.0$ & $30 \pm 1.0$ & 70 \\
\hline 0.38 & $27 \pm 0.58$ & $15 \pm 0.0$ & 85 \\
\hline
\end{tabular}

Table 5: Effect of imidacloprid on the development of the house fly in a treated medium containing third instar larvae (solid baits).

\begin{tabular}{|c|c|c|c|}
\hline $\begin{array}{c}\text { Concentration } \\
\text { (\%) }\end{array}$ & Pupation (\% $\mathbf{~ S D )}$ & $\begin{array}{c}\text { Emergence (\% } \\
\mathbf{\pm} \text { SD) }\end{array}$ & $\begin{array}{c}\text { Inhibition of Adult } \\
\text { Emergence (\%) }\end{array}$ \\
\hline 0.0 & $100 \pm 0.0$ & $93 \pm 0.58$ & 7 \\
\hline 2 & $93 \pm 0.58$ & $75 \pm 1.0$ & 25 \\
\hline 4 & $83 \pm 0.58$ & $55 \pm 1.0$ & 45 \\
\hline 6 & $62 \pm 0.58$ & $35 \pm 0.0$ & 65 \\
\hline 8 & $52 \pm 0.58$ & $18 \pm 0.58$ & 82 \\
\hline 10 & $33 \pm 0.58$ & $10 \pm 0.0$ & 90 \\
\hline 12 & $30 \pm 1.0$ & $5 \pm 0.0$ & 95 \\
\hline
\end{tabular}

Table 6: Effect of boric acid on the development of the house fly in a treated medium containing third instar larvae (solid baits).

\begin{tabular}{|c|c|c|c|}
\hline $\begin{array}{c}\text { Concentration } \\
\text { (\%) }\end{array}$ & $\begin{array}{c}\text { Pupation (\% } \\
\mathbf{\pm} \text { SD) }\end{array}$ & $\begin{array}{c}\text { Emergence (\% } \mathbf{~} \\
\text { SD) }\end{array}$ & $\begin{array}{c}\text { Inhibition of Adult } \\
\text { Emergence (\%) }\end{array}$ \\
\hline 0.0 & $100 \pm 0.0$ & $100 \pm 0.0$ & 0 \\
\hline 2 & $90 \pm 0.58$ & $88 \pm 1.0$ & 12 \\
\hline 4 & $80 \pm 0.58$ & $78 \pm 0.58$ & 22 \\
\hline 8 & $60 \pm 0.58$ & $55 \pm 0.58$ & 45 \\
\hline 10 & $45 \pm 0.58$ & $43 \pm 0.58$ & 57 \\
\hline 12 & $33 \pm 0.58$ & $30 \pm 1.0$ & 70 \\
\hline 16 & $15 \pm 1.0$ & $10 \pm 0.58$ & 90 \\
\hline
\end{tabular}

Table 7: Effect of borax acid on the development of the house fly in a treated medium containing third instar larvae (solid baits).

\begin{tabular}{|c|c|c|c|c|c|c|}
\hline Compounds & $\begin{array}{c}\text { IC values } \\
\%\end{array}$ & $\begin{array}{l}\text { Pupation } \\
\text { (\% } \% \text { SD) }\end{array}$ & $\begin{array}{c}\text { Emergence } \\
(\% \pm \text { SD) }\end{array}$ & $\begin{array}{l}I^{I} C_{90} I \\
I C_{25}\end{array}$ & Slope & $\begin{array}{l}\text { Relative } \\
\text { Efficiency }\end{array}$ \\
\hline & 25 & 50 & 90 & & & \\
\hline Imidacloprid & 0.027 & 0.083 & 0.67 & 8.1 & 1.41 & 68.8 \\
\hline Boric acid & 2.1 & 3.7 & 11.6 & 3.1 & 2.6 & 1.5 \\
\hline Borax & 2.8 & 5.74 & 21.1 & 3.7 & 2.26 & 1 \\
\hline
\end{tabular}

Table 8: Relative efficiency and IC values of tested compounds in solid formulation against third instar larvae of the house fly M. domestica.

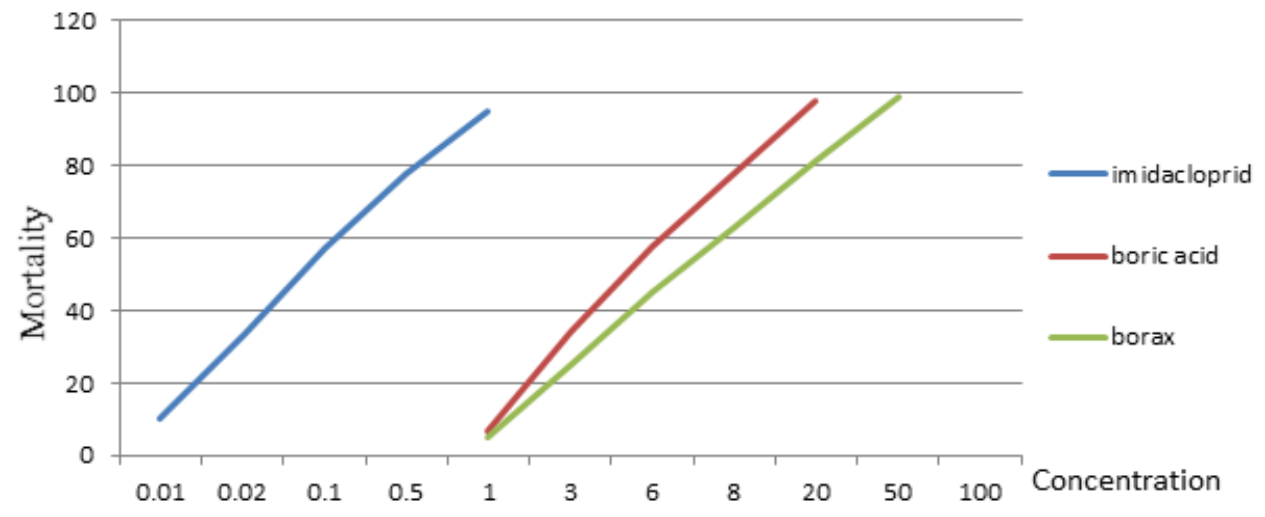

Figure 8: IC-P-lines for the effect of tested compounds on the inhibition of adult emergence after treated of third instar larvae (solid formulation).

formulation. For boron compounds, the inhibition of adult emergence was generally greater in those larvae treated by ATSB as liquid baits compared to dry formulation. Form probit analyses the $\mathrm{IC}_{50}$ were $0.19 \%$ and $2.6 \%$ in liquid baits and 3.7 and 5.7 for dry baits when larvae treated with boric acid and borax respectively. Also, data demonstrated that the effects of tested compound on both pupation (larval-to-pupal development) and emergence were significantly reduced at the high concentration of boron compounds. Concentrations needed were considerably greater than the effective concentration for imidacloprid. The relative efficiency revealed that, imidacloprid and boric acid 31.3 and 13.7 times more suppression of adult emergence than borax when larvae treated as liquid baits. In dry formulation baits, it is clear that imidacloprid 68.8 times and boric acid 1.5 times as to toxic as borax.

In a previous studies using imidacloprid, as Larvicidal activity was observed in the direct surrounding of treated animals $[67,68]$. Arther et al. concluded that monthly imidacloprid application of 7.5 to $10 \mathrm{mg} / \mathrm{kg}$ will rapidly kill existing and reinvesting flea infestation in dog and break the flea life cycle by killing adult fleas before egg production begins [69-74]. Previous works mentioned that the ability of imidacloprid to suppress the yield of adult fleas on carpate (6-hours exposure) steadily declined from $82 \%($ Day +2$)$ to $12 \%($ Day +43$)$ [75-81]. Previous works mentioned that $\mathrm{LC}_{50}(84 \mathrm{Nano}$-gram/L) of imidacloprid to larvae of Aedes aegypti. Uragayala et al. evaluated the Larvicidal effect of neonicotinoid insecticides against susceptible and resistant mosquito's strains [82-96].

Boron compounds were the standard chemical use for control of larval moscoid fly population in manure [97-105], sewage ludge [106111] and compost [112]. Recently, Hinkle et al. [113,114] mentioned borate compounds varied in efficiency against larval of cat fleas. The $\mathrm{LC}_{50}$ values of larvae exposed in treated carpet for $96 \mathrm{~h}$ were $23 \mu \mathrm{g} / \mathrm{cm}^{2}$ for powder boric acid, $40 \mu \mathrm{g} / \mathrm{cm}^{2}$ for granular boric acid and $47 \mu \mathrm{g} / \mathrm{cm}^{2}$ for granular polybor. Shahiduzzaman [115-119] suggested that boric showed highest Larvicidal effect (78.9\%) followed by borax (68.9\%) against larva.

\section{Conclusion}

Imidacloprid has the greatest fatal effect at both $\mathrm{IC}_{50}$ and $\mathrm{IC}_{90}$ levels followed by boric acid and then borax. In the liquid formulation, the 
Citation: Amin AA, Soliman MH, Shalaby AA (2017) Evaluation of the Efficiency of Certain Attractive Toxic Baits for the Control of the House Fly, Musca domestica (Diptera: Muscidac). Chem Sci J 8: 170. doi: 10.4172/2150-3494.1000170

Page 6 of 8

relative efficiency for imidacloprid and boric acid compared to borax (the least potent one), imidacloprid and boric acid achieved 31.3 and 13.7 times more suppression of adult emergence than borax. In the solid formulation, it's clear that imidacloprid 68.8 times and boric acid 1.5 times as toxic as borax. The efficiency of tested compounds as liquid baits is higher than it as dry baits.

\section{References}

1. Abass N, Crickmore N, Shad SA (2015) Efficacy of insecticide mixtures agains a resistant strain of house fly (Diptera: Muscidae) collected from a poultry farmi. International Journal of Tropical Insect Science 35: 48-53.

2. Abbot WS (1925) A method of computing the effectiveness of an insecticide. J Econ Entomol 18: 265-267.

3. Acevedo GR, Zapater M, Toloza AC (2009) Insecticide resistance of house fly Musca domestica(L) from Argentina. Parasitol Res 105: 489-493.

4. Agrawal VK, Agrawal A, Choudhary V, Singh R, Ahmed N, et al. (2010) Efficacy of imidacloprid and fipronil gels over synthetic pyrethroid and propoxur aerosols in control of German cockroaches (Dictyoptera: Blatellidae). J Vector Borne Dis 47: 139-144.

5. Ahmed FM, Khalequzzaman M (2001) Malathion tested for synergism with cypermethrin phosalon phorate and fenitrothion on musca domestica L. J Biological Science 11: 1028-1030.

6. Ahmed FS (2015) Toxicological studies on boric acid, imidacloprid and fipronil and their binary mixtures as insecticides on German cockroach blattella germanica L. (Dictyoptera: Blattellidae). Cairo University.

7. Ahmed S, Ansari MS, Ahmed N (2013) Acute toxicity and sub-lethal effects of the neonicotinoid imidacloprid on the fifness of Helicoverpa armigera (Lepidoptera: Noctuidae). International Journal of Tropical Insect Science 33: 264-275

8. Ali A, Xu RD, Barnard DR (2006) Effects of sub-lethal exposure to boric acid sugar bait on adult survival, host-seeking, blood feeding behavior and reproduction of Stegomia albopicta. J Am Mosq Control Assoc 22: 464-468.

9. Appel AG (1992) Performance of gel and pastes bait products for German cockroach (Dictyoptera: Blattellidae) control. Laboratory and field studies. J Econ Entomol 85: 1176-1183.

10. Appel AG, Tanley MJ (2000) Laboratory and field performance of an imidacloprid gel bait against German cockroaches (Dictyoptera: Blattellidae). J Econ Entmol 93: 112-115.

11. Archer RG, Cunningham J, Dorn H, Everett R, Herr LG, et al. (1997) Efficiency of imidacloprid for removal and control fleas (cienocepho ides flies) on dogs. Am J Vet Res 58: 848-885.

12. Attique NNR, Khaliqu A, Sayyed AH (2006) Could resistance to insecticides in plutella xylostella (lap plutellidae) be overcome by insecticide mixture. J Appe Entomol 130: 122-127.

13. Balme GR, Denning SS, Watson DW (2013) Boric acid Aversion in adult house flies Musca demestica. J Agric Urban Entomol 29: 85-92.

14. Bao H, Liu S, Gu J, Wang X, Liu Z (2009) Sub-lethal effects of four insecticides on the reproduction and wing formulation of brown plant hopper. Nilaparrata lungens. J Pest Manaf Sci 65: 170-174.

15. Barin A, Arabkhazaeli F, Rahbari S, Madan SA (2010) The housefly Musca domestica as possible mechanical vector of Neweasyle disease virus in the laboratory and field. Medical and Veterinary Entomol 24: 88-90.

16. Beierm JC, Muller GC, Weidong GU, Arheart KL, Schlein Y (2012) Attractive toxic sugar bait (ATSB) methods decimate populations of Anopheles malaria vectors in arid environments regardless of the local availability of favoured sugar-source blossoms. Malaria Journal 11: 1-31.

17. Boina DR, Onagbola EO, SAlyani M, Stelinski LL (2009) Antifeedant and sub-lethal effects of imidacloprid on Asian citrus psyllid, Diaphorina citri. Pest Manag Sci 65: 870-877.

18. Borchert JN, Davis RM, Poche RM (2009) Field efficacy of rodent bait containing the systemic insecticide imidacloprid against the fleas of California ground squirrels. J Vector Encology 34: 92-98.

19. Borkovec AB, Settepani JA, Labrecque GC, Fye RL (1969) Boron compounds as Chemosterilants for house flies. J Econ Entmol 62: 1472-1480.
20. Burns EC, Tower BA, Bonner FL, Austin HC (1959) Feeding polybor 3 for control under caged layers. J Econ Entomol 52: 446-448.

21. Chapman PA, Morgan CP (1992) Insecticide resistance in Musca domestica L from eastern England. Pestic Sci 36: 35-45.

22. Corbel V, Raymond M, Chundre F, Hougard JM (2004) Efficiency of insecticides mixture against larvae of Culex quinquefasciatus Say (Diptera: Culicidae) resistant to pyrethroids and carbamates. Pest Manag Sci 60: 375-380.

23. Crawley SE, Gordon JR, Kowles KA, Potter MF, Haynes KF (2017) Imact of sublethal exposure to a pyrethroid - neonicotinoid insecticide on mating fecundity and development in the bed bug Cimex lectularius I. (Hemiptera: Cimicidae). PLoS ONE 10: 1-14.

24. Curtis CF (1985) Theoretical models of the use of insecticide mixture for management of resistance. Bull Entomol Res 75: 259-265.

25. Darriet F, Corbel V (2006) Laboratory evaluation of pyriproxyfen and spinosad alone and in combination against Aedes aegypti larvae. J Med Entomol 43 1190-1194.

26. Desneux N, Decourty A, Delpuech JM (2007) The sub-lethal effects of pesticides on beneficial arthropods. Anna Rev Entomol 52: 81-106.

27. Diaferia M, Veronesi F, Fiorett DP, Guerra A, Riglli M (2005) The sub-lethal effects of pesticides on beneficial arthropods. 46: 108-115.

28. Duncan DB (1955) Hepatoprotective, DNA Damage Prevention and Antioxidant Potential of Spirulina platensis on CCl4-Induced Hepatotoxicity in Mice Multiple range and multiple F-test. Biometrics 11: 1-42.

29. Ebeling W (1995) Inorganic insecticides and dusts. In: Rust MK, Owens JM Reierson DA (eds.). Understanding and controlling the German cockroach. Oxford University Press, New York, USA, pp: 193-230.

30. Farooq M, Freed D (2016) Combined effects of Beauveria bassiana (Hypocreales: Clavicipitaceae) and insecticide mixtures on biological parameters of Musca domestica (Diptera: Muscidae). Pakistan J 48: 1465-1476.

31. Finney DJ (1971) Probit analysis: a statistical treatment of the sigmoid response curve. Cambridge University Press. Accessed on: 02 August 1982.

32. Förster M, Klimpel S, Mehlhorn H, Sievert K, Messler S, et al. (2007) Pilot studies on synantropic flies (e.g. Musca, Sarcophaga, Calliphora, Fania, Lucilia, Stomoxys) as vectors of pathogenic micro-organisms. Parasitol Res 101: 243-246.

33. Fulcher A, Scott JM, Qualls WA, Müller GC, Xue RD (2014) Attractive Toxic Sugar Baits Mixed with Pyriproxyfen Sprayed on Plants Against Adult and Larval Aedes albopictus (Diptera: Culicidae). J Med Entomol 5: 896-899.

34. Gore JC, Schal C (2004) Laboratory evaluation of boric acid-sugar solution as baits for management of German cockroach infestations. J Econ Entomol 97 581-587.

35. Greenberg B (1971) Flies and Diseases. Volume 1. Princeton University Press, Princeton, NJ, USA, p: 856

36. Hayash A (1969) Joint action of pyrethoids against house flies. J Midic Entomo and Zoology 4: 261-263.

37. Hemingway J, Ranson H (2000) Susceptibility of Culex quinquefasciatus (Diptera: Culicidae) to malathion in Sargodha district Insecticide resistance in insect vectors of human disease. Anne Rev Entomol 45: 371-391.

38. He YX, Zhao JW, Wu DD (2011) Sub-lethal effects of imidacloprid on Bemisia tabaci (Hemiptera: Aleyrodidae) Under laboratory conditions. J Econ Entomol 104: 833-838.

39. Hinkle NC, Koelher PG, Ptterson RS (1995) Larvicidal effects of boric acid and disodium octaborate to cate fleas (Siphonaptera: Pulicidae). J Med Ento ol 32: 424-427.

40. Hogsett JA, Koehler PQ (1994) Repellency of aqueous solution of boric acid and polybor 3 to house flies (Dipter: Muscidae). J Econ Entomol 95: 1110-1112.

41. Hogsette JA, Koehler PG (1992) Comparative toxicity of aqueous solutions of boric acid and polybor 3 to house flies (Diptera: Muscidae). J Econ Entomol 85: 1209-1212.

42. Hogest JA, Carlson DA, Nejame AS (2002) Development of Granular boric acid sugar baits for house flies (Diptera:Muscidae). J Econ Entomol 95: 1110-1112.

43. Hopkin TJ, Woodley L, Gyr P (1997) Imidacloprid topical formulation Larvicida effect against (ctenocephalides flies) in the surrounding of treated doge. Suppl Com Con Pracl Vet 19: 4-10. 
Citation: Amin AA, Soliman MH, Shalaby AA (2017) Evaluation of the Efficiency of Certain Attractive Toxic Baits for the Control of the House Fly, Musca domestica (Diptera: Muscidac). Chem Sci J 8: 170. doi: 10.4172/2150-3494.1000170

Page 7 of 8

44. Hougard JM, Corbel V, Guessan RN, Darriet F (2003) Efficacy of mosquito nets treated with insecticide mixtures or mosaics against insecticide resistant Anopheles gambiae and Culex quinquefasciatus (Diptera: Culicidae). 93: 491-998.

45. Islam MZ, Khalequzzaman M (2002) Potentiation of malathion by other insecticides against adult housefly. Pakistan J Biologscien 5: 299-302.7

46. Jacobs DE, Hatchinson MJ, Ewaldhumm D (2000) Inhibition of immature Ctenocecephaides flies (Siphonoptera: Pulicid) development in the immediate environment of cats treated with imidacloprid. J Mea Entom 7: 228-230.

47. Jin BL, Sulaiman S, Othman HF (2008) Evaluation of imidacloprid against the housefly Musca domestica Linnaeus in the Laboratory. J Trop Med Parasitol 31: 223-273.

48. Kaufman PE, Gerry CA, Rutz AD, Scott JG (2006) Monitoring susceptibility of house flies (Musca demestic). In United States to imidacloprid. J Agric Urban Entomol 23: 195-200.

49. Kaufman PE, Scott JG, Rutz DA (2001) Monitoring insecticide resistance in house flies (Diptera: Muscidae) from New York dairies. Pest Manag Sci 57: 514-521.

50. Keiding $\mathrm{J}$ (1999) The housefly biology and control training and information guide (advanced level). Geneva, World Health Organization 86: 937.

51. Khan HAA, Akram W, Shaet SA, Lee JJ (2013) Insecticide mixtures could Enhance the toxicity of insecticides in resistant daily population of Musca domestica L. PLoS ONE 8: 1-8.

52. Klotz JH, Greenberg L, Amrhein C, Rust MK (2000) Toxicity and Repellency of Borate Sucrose water Baits to Argentin Ants (Hymenopter: Formicidae). J Econ Entmol 93: 1256-1258.

53. Klotz JH, Moss JI, Zhao RL, Davis R, Patterson RS (1994) Oral toxicity of boric acid and other boron compounds to immature cat fleas (Siphonaptera: Pulicidae). J Econ Entomol 87: 1534-1536.

54. Klotz JH, Oi DH, Vail KM, Williams DF (1996) Laboratory evaluation of a boric acid liquid bait on colonies of Tapinomamel anocephalum Argentine ants and Pharaoh ants (Hymenoptera: Formicidae). J Econ Entomol 89: 673-677.

55. Klotz JH, Vail KM, Williams DF (1997) Liquid boric acid baits for control of structural infestations of pharaoh ant (Hymenoptera=Formicidae). J Econ Entomol 9: 523-526

56. Klunker R, Kiesow I (1980) Rearing the common house fly Musca domestica $(\mathrm{L})$ in small cages. Angew Parasite 21: 100-114.

57. Klunker R, Scheurer S, Neumann T (1990) Control of the pharaoh's ant with borax bait formulations. Z Gesamte Hyg 36: 664-667.

58. Kramer F, Mencke N (2001) Flea biology control the biology of the cat flea contro and prevention with imidacloprid in small animals. Springer, New York, USA.

59. Langford GS, Johnson WT, Harding WC (1954) Bait studies for fly control. J Econ Entomol 47: 438-441.

60. Lang JT, Treece RE (1972) Boric acid effects on face fly fecundity. J Econ Entmol 65: 740-741.

61. Lashkari MA, Shragard A, Ghadamyari M (2007) Sublethal effects of imidacloprid and Pymetrozine on population growth para meters of cabbag aphid, Brevicoryne brassicae on rapeseed, Brassic napus L. Insect Science 14: 207-212.

62. Lee CY (2000) Sub lethal effects of insecticides on longevity fecundity and behavior of insect pests a review. Bioscience $\mathrm{J}$ 11: 107-112.

63. Lu YH, Zheng XS, Goe XW (2016) Sub lethal effect of imidacloprid on the fecundity longevity and enzyme activity of Sitobion avenae (Fabricius) and Rhopalosiphum padi (Linnaeus). Bull of Entomol Res 106: 551-559.

64. Luin YX (2000) Insecticide resistance and cross resistance in the house fly (Diptera: Muscidae). J Econ Entom 93: 1269-1275.

65. Mahmoudv M, Abbaspour H, Garjan AS, Bandani AR (2012) Decrease in population and adult emergence of Plutella xylostella (I.) treated with hexaflumuron. Chilean Journal of Agricultural Research 72: 206-211.

66. Malik A, Singh N, Satya S (2007) House fly (Musca domestica): a review of control strategies for a challenging pest. J Environ Sci HIth Part B 42: 453-469.

67. Mansour SA, Baker RA, Mohammed RI, Hassaneen NM (2011) Larvicida activity of some botanical extracts, commercial insecticides and their binary mixtures against the housefly, Musca domestica L. J Open Toxinology 41: 1-13.
68. Marshall JM, White MT, Ghani AC, Schlein Y, Muller GC, et al. (2013) Quantifying the mosquito's sweet tooth: modelling the effectiveness of attractive toxic sugar baits (ATSB) for malaria vector control. Malar J 12: 291.

69. Mascari TM, Foil LD (2010) Laboratory evaluation of insecticide-treated sugar baits for control of phlebotomine sand flies (Diptera: psychodidae). J Am Mosq Eontrol Assoc 26: 398-402

70. Migg HN, Simpson SE (1997) Use of borax toxicants to control tephnitidae fruit flies. US Patent 5: 698-208.

71. Migley AR, Muller WO, Dunklee DE (1943) Borax and boric acid for control of flies in manure. J Am Soc Agrom 35: 779 - 785.

72. Miguelena JG, Baker PB (2014) Evaluation of Liquid and Bait Insecticides against the Dark Rover Ant (Brachymyrmex patagonicus). Insects 5: 832-848.

73. Moriarty F (1969) The sub lethal effects of insecticides in insects. Bio Rev 44 321-357.

74. Mothap NP (2016) The attractiveness of toxic bait is not always accompanied by increased mortality in laboratory colonies of Argent in ants, Linepi thema humil (Hymenoptera=Formicidae). Entomological Society of Southern Africa.

75. Mullens BA, Rodriguez JL (1992) Effects of disodium octaborate tetrahydrate on survival, behavior, and egg viability of adult moscoid flies (Diptera=Muscidae) $\mathrm{J}$ Econ Entomol 85: 137-143.

76. Müller GC, Junnila A, Schlein Y (2010) Effective Control of Adult Culex pipiens by Spraying an Attractive Toxic Sugar Bait Solution in the Vegetation Near Larval Habitats. J Med Entomol 47: 63-66.

77. Müller GC, Schlein Y (2011) Different methods of using attractive sugar baits (ATSB) for the control of Phlebotomus papatasi. J Vector Ecol 36: 64-70.

78. Mustafa AA, Allam KA, Badr KA, El-Dib VA (1996) Recent toxicological studies on adult housefly Musca domestica (L.) in some Egyption Governorates. Egypt J Med Sci 17: 537-546.

79. Nazi WA, Seleena B, Lee HL, Jeffery JT, Rogayah TAR, et al. (2005) Bacteria fauna from the house fly Musca domestica (L). Tropical Biomedicine 22: 225-231.

80. Othman DA (2014) Biochemical mechanism insecticide resistance in the housefly from certain Governorates in Egypt. PhD Thesis, Faculty of Science, Ain Shams University, Cairo, Egypt.

81. Otranto D, Paradis P, Lia RP, Latrofa MS, Testini G, et al. (2007) Combination of $10 \%$ imidacloprid / $50 \%$ permethrin for the pervention of leishmaniasis in Kenne led dogs in an endemic area. Vet Parasit 144: 270-278.

82. Pospischil R (2003) Fly control under field conditions with imidacloprid fly bait Proceedings of the European Poultry Symposium, pp: 109-113.

83. Pospischil R, Junkersdorf J (2002) Imidacloprid fly bait - A fact acting formulation against flies in livestock. Proceedings 4 Int. Conf. Ins Pests in Urban Environment. Charleston, USA 457: 458.

84. Pospischil V, Junkersdorf K, Horn K (2005) Control of house flies, Musca domestica (Diptera: Muscidae), with imidacloprid WG 10 in pig farms. In: Lee $\mathrm{CY}$, Robinson WH. Proceedings of the Fifth International Conference on Urban Pests, "Singapore.

85. Rabhi KK, Esancy K, Voisin A, Crespin L, Lecorre J, et al. (2012) Unexpected effects of low doses of a neonicolinoid insecticide on behavioral responses to sex pheromone in a pest insect. PLoS ONE 9: e11441.

86. Ross DH, Ather RG, Simson CV, Doyle V, Dryden MW (2012) Evaluation of the efficacy of topically administered imidacloprid+pyriproxyfen and orally administered spinosad against cat fleas (Ctenocephalides felis): Impact of treated dogs on flea life stages in a simulated home environment. Parasites and Vectors 5: 192.

87. Rupes V, Chmela J, Mazanek L, Vlckova J (2008) A novel imidacloprid bait for control of Monomorium pharaonis (hymenoptera: formicidae). Proceeding of sixth International Conference on Uraban Pests.

88. Rust MK, Reierson DA, Klotz JH (2004) Delayed toxicity as a critical factor in the efficacy of aqueous baits for controlling Argentin ants (Hymenoptera: Formicidae). J Econ Entmol 97: 1017-1024.

89. Sasaki T, Kobayashi M, Agui N (2000) Epidemiological potential of excretion and regurgitation by Musca domestica (Diptera: Muscidae) in the dissemination of Escherichia coliO157: $\mathrm{H} 7$ to food. J Med Entomol 37: 945. 
Citation: Amin AA, Soliman MH, Shalaby AA (2017) Evaluation of the Efficiency of Certain Attractive Toxic Baits for the Control of the House Fly, Musca domestica (Diptera: Muscidac). Chem Sci J 8: 170. doi: 10.4172/2150-3494.1000170

Page 8 of 8

90. Satpathy S, Kumar A, Shivalingaswarmy TM, Rai AB (2012) Effect of foliar spray of boron on biology, egg laying activity and control of brinjal shoot and fruit borer (Leucinodes orbanalis Guen). Indian J Hort 69: 295-298.

91. Scott JG, Alefantis TG, Kaufman PE, Rutz DA (2000) Insecticide resistance in house flies from caged - layer poultry facilities. Pest Manag Sci 56: 147-153.

92. Settepani JA, Crystal MM, Borkovec AB (1969) Boron Chemosterilants against screw - worm flies structure - activity relationship. J Econ Entomol, pp: 375-383.

93. Shalaby AA, Mostafa AA, Allam KA (2002) Field studies on the susceptibility of housefly to certain insecticides in nine Egyptian governorates. J Egypt Soc Parasitology 32: 91-97.

94. Sharfifard M, Mossadeg MS, Vazirianzadeh B, Mahmoudabadi A (2011) Interaction between entomopathogenic fungus, Metarhizium anisopliae and sublethal deses of spinosad for control of house fly, Musca domestica. Iran. J Arthopod Born Dis 5: 28-36

95. Sherwood DH (1959) Effect of polybor 3 on egg production. Poult Sci 38: 491-493.

96. Shono T, Scott JG (2003) Spinosad resistance in the house fly, Musca domestica, is due to a recessive factor on autosome-1. Pestic Biochem Physiol 75: $1-7$.

97. Stewart ZP, Oxborough RM, Tungu PK, Kirby MJ, Rowl MW (2013) Indoor Application of Attractive Toxic Sugar Bait (ATSB) in Combination with Mosquito Nets for Control of Pyrethroid-Resistant Mosquitoes. PLoS ONE 8: 084168.

98. Strong CA, Koehler PG, Patterson RS (1993) Oral Toxicity and repellency of borates to German cockroaches (Dictyoptera: Blatellidae). J Econ Entomol 86: 1458-1463.

99. Sulaiman S, Othman MZ, Aziz AH (1999) Isolation of Enteric Pathogens from Synanthrope Flies Trapped in Downtown Kuala Lumpur. J Vector Ecology 25: 9-93.

100.Sun YP (1950) Toxicity index and improved method of comparing the relative toxicity of insecticides. J Econ Entmol pp: 43-53.

101. Taillebois E, Thany SH (2016) The Differential effect of low-dose mixtures of four pesticides on the pea aphid Acyrthosiphon pisum. Insects 7: 53 .

102. Tan Y, Biond A, Desneux A, Gao XW (2012) Assessment of physiological sub lethal effects of imidacloprid on the mirid bug Apolygus. Lucorum Ectoxicolog 21: 1989-1997.

103. Thaddeus K, Graczy K, Knight R, Tamany L (2005) Mechanical Transmission of Human Protozoan Parasites by Insects. Clinical Microbiology Reviews, pp: 128-132.

104. Thompson SR, Brandebburg RL (2006) Effect of combining imidacloprid and diatomaceous earth with Beauveria bassiana on mole cricket (Orthopetre: Gryllotaplad) mortality. J Econ Entomol 99: 1948-1954.

105. Tomlin C (1994) The Pesticide Manual (A World Compendium). 10th edn.
The British Crop Protection Council and The Royal Society of Chemistry. Cambridge, England, UK, pp: 591-593.

106. Toppozad A, Mohamed MA, Eldefrawi ME (1967) Resistance of the house fly (Musca domestica L.) to insecticides in Eygpt. Bull Wld Hlth Org 36: 937-948.

107. Tower BA, Burns EC, Aust C, Bonner FL (1960) The performance of caged layers fed varying percentages of borax in the ration. Poult Sci 39: 1190-1193.

108. Weir RJ, Fisher RS (1972) Toxicological studies on borax and boric acid Toxicol. Appl Pharmacol 23: 351-364.

109. White WH, McCoy CM, Meyer JA, Winkle JR, Plummer PR, et al. (2007) Knockdown and mortality comparisons among spinosad, imidacloprid and methomyl containing baits against susceptible Musca domestica (Diptera: Muscide) under laboratory condition. J Econ Entomol 100: 155-163.

110. Xue RD, Ali A, Kline DL, Bornard DR (2008) Field evaluation of boric acid and fipronil - based bait stations against adult mosquitoes. J Am Mosq Control Assoc 24: 415- 418

111. Xue RD, Barnard DR (2003) Boric acid bait kill adult mosquitoes (Diptera: Culicidae). J Eco Entomol 96: 1556-1562.

112. Xue RD, Kline DL, Ali A, Barnard DR (2006) Application of boric acid baits to plant foliage for adult mosquito control. J Am Mosq Control Asso, pp: 497-500.

113. Xue RD, Muller GC, Kline DL, Barnard DR (2011) Effect of application rate and persistence of boric acid sugar baits applied to plants for control of Aedes albopictus. J Am Mosq Control Assoc 27: 56-60.

114. Yang LK, Nigg HN, Simpson SE (2000) Sodium tetraborate effects on mortality and reproduction of Anastrepha suspense (Diptera: tephritidae). J Econ Entmol 93: 1485-1452.

115. Yan S (2005) Evaluation of local pathogenic fungi, boric acid and their potential synergism for control of the European fire ant, Myrmica rubra (L.). MSc Thesis, Graduate School Main University.

116. Zarrin MV, Azirianzadeh B, Shams SS, Zarei M, Abadi A, et al. (2007) Isolation of fungi from house fly (Musca domestica) in Ahvaz, Iran. Pakistan Journal of Medical Sciences 20: 917-919.

117. Zayed AB, Shalaby AA, Mostafa AA, Allam KA, Osman MZ (2004) Resistance to insecticides and prevalence of enzyme mechanisms in populations of the housefly Musac domestica (L.) (Diptera: Muscidae). J Union Aral Biol Cairo Zoology 21: 59-7.

118. Zurek L, Gor JC, Stringham MS, Watson DW, Wald Vogel M, et al. (2003) Boric acid dust as a component of an integrated cockroach management program confined swine production. J Econ Entomol 96: 1362 -1366.

119. Zurek L, Watson DW, Scel C (2002) Synergism between Metarhizium anisopliae (Deuteromycotina: Hyphomycetes) and boric acid against the German cockroach (Dictyoptera: Blattellidae). J Bio Control 23: 296-302. 